\title{
HUBUNGAN KEBIASAAN SARAPAN DAN STATUS HIDRASI DENGAN KONSENTRASI BERFIKIR PADA REMAJA
}

\author{
Banun Lentini, Ani Margawati*) \\ Program Studi Ilmu Gizi Fakultas Kedokteran Universitas Diponegoro \\ J1.Dr.Sutomo No.18, Semarang, Telp (024) 8453708, Email : gizifk@undip.ac.id
}

\begin{abstract}
Background: Nutritional problems in adolescents have negative impact on the level of public health. Nutritional problems include anemia and underweight. The prevalence of underweight adolescents is approximately 30\% 40\%. Nutritional status of adolescents is influenced by their food patterns, such as limited food avalibilty resction.The are not used to breakfast tend to have low achievement in their school. Not having breakfast can affect hydration status and laters is collerated to the concentration.

Objective: Determine correlations of breakfast and hydration status with the concentration ability in adolescents Methods: This cross sectional study included 80 adolescents selected using random sampling method. Data on hydration status was measured using urine specific gravity indicator. Data on ceoncentration was obtain using the Digit Symbol Test learning and Digit Span Test from the WAIS subtest (Weschler Adult Intelligence Scale) performed by a certified institute of applied psychology. Data on breakfast habits was obtain using questionnaires. Results: There are 52,5\% of the subjects have breaksfast behavior and 47,5\% the subjects didn't have breaksfast behavior. The mean of concentration urine obtained that $70 \%$ of the subjects were dehydration and $30 \%$ of the subjects of the subjects wasn't dehydration (normal). The mean of concentration test score was $51,75 \%$ of the subjects had a hight concentration and $46.25 \%$ of the subjects had a low concentration ability. There was a significant correlation between breakfast and concentration ability $(p=0.00)$. There was no significant correlation between hydration status and concentration ability $(p=0.35)$.
\end{abstract}

Conclusion: breakfast is related to concentration ability but hydration status is unrelated to concentration ability Keywords: adolescents; breakfast; hydration status; concentration ability

\begin{abstract}
ABSTRAK
Latar Belakang : Masalah gizi pada remaja akan berdampak negatif pada tingkat kesehatan masyarakat. Masalah gizi tersebut antara lain anemia dan IMT kurang dari batas normal atau kurus. Prevalensi remaja dengan IMT kurus berkisar antara $30 \%$ - $40 \%$. Keadaan status gizi remaja salah satunya dipengaruhi oleh pola konsumsi makan yaitu keterbatasan makanan atau membatasi sendiri makanannya karena faktor ingin langsing. Selain itu masalah gizi pada remaja adalah rendahnya kebiasaan sarapan. Remaja yang tidak terbiasa melakukan sarapan 79,2\% mempunyai prestasi sekolah yang kurang. Tingginya angka remaja yang tidak terbiasa sarapan berpengaruh pada status hidrasi yang berkorelasi terhadap konsentrasi berfikir.

Tujuan: Menganalisis hubungan antara kebiasaan sarapan dan status hidrasi dengan konsentrasi berfikir pada remaja.

Metode:Penelitian ini menggunakan desain cross sectional. Subjek pada penelitian ini adalah remaja perempuan. Jumlah subjek sebanyak 80 remaja dipilih menggunakan metode simple random sampling. Pengambilan data status hidrasi menggunakan indikator berat jenis urin. Data konsentrasi berfikir menggunakan Digit Symbol Test dan Digit Span Test dari subtest WAIS (Weschler Adult intelegence Scale) yang dilakukan oleh lembaga psikologi terapan yang tersertifikasi. Data kebiasaan sarapan dikumpulkan berdasarkan wawancara dengan kuesioner.

Hasil : Sebanyak 52,5\% siswa terbiasa melakukan sarapan dan 47, 5 \% subjek tidak terbiasa melakukan sarapan. Dari hasil analisis berat jenis urin didapatkan sebanyak 70 \% subjek mengalami dehidrasi dan $30 \%$ tidak dehidrasi (normal). Berdasarkan hasil test konsentrasi tersebut didapat 48,25\% subjek memiliki kemampuan konsentrasi rendah dan 51,75\% memiliki kemampuan konsentrasi tinggi. Terdapat hubungan yang signifikan antara kebiasaan sarapan dan konsentrasi berfikir $(p=0,00)$. Tidak terdapat hubungan antara status hidrasi dengan konsentrasi $\operatorname{berfikir}(p=0,35)$
\end{abstract}

Kesimpulan :Terdapat hubungan antara kebiasaan sarapan dengan konsentrasi berfikir. Tidak terdapat hubungan antara status hidrasi dengan konsentrasi berfikir.

Kata Kunci : Remaja; kebiasaan sarapan; status hidrasi; konsentrasi berfikir

\section{PENDAHULUAN}

Masa remaja merupakan masa rentan terhadap masalah gizi. Pada masa ini merupakan periode pertumbuhan dan pematangan reproduksi.
Pertumbuhan menyebabkan perubahan fisik yang berpengaruh terhadap kebutuhan dan kecukupan asupan zat gizi. Ketidakseimbangan antara 
kebutuhan dan kecukupan akan berdampak pada masalah gizi baik gizi lebih maupun gizi kurang. ${ }^{1}$

Keadaan gizi kurang pada remaja khususnya remaja putri diakibatkan oleh diet yang ketat, kondisi ekonomi, kebiasaan makan yang buruk serta kurangnya pengetahuan gizi. Hal tersebut dapat menyebabkan menurunnya daya tahan tubuh sehingga mengganggu aktivitas belajar serta menurunnya prestasi belajar. ${ }^{2}$

Sarapan adalah makanan yang dimakan sebelum beraktivitas yang terdiri dari makanan pokok dan lauk pauk atau makanan kudapan yang biasa dilakukan pada pagi hingga menjelang siang hari. Sarapan memberikan kontribusi yang penting terhadap total asupan gizi sehari karena dapat menyumbangkan sekitar 25\% total asupan gizi sehari. Selain itu sarapan yang baik mengandung sumber karbohidrat, protein, serat tinggi dan lemak rendah. ${ }^{3}$ Menurut Rampersaud, sebaiknya energi dari makanan sarapan dapat menyumbang minimal $20 \%$ dari total asupan energi. ${ }^{4}$

Bagi pelajar, sarapan berguna dalam meningkatkan konsentrasi dan daya ingat ketika belajar di sekolah sehingga akan menghasilkan prestasi yang lebih baik. ${ }^{5}$ Penelitian di Semarang menyebutkan rendahnya kesadaran tentang pentingnya sarapan ditunjukkan pada penelitian di SD Citarum Semarang yang menyebutkan terdapat $34,83 \%$ siswa melewatkan sarapan. ${ }^{6}$ Pada penelitian Laksmi mengenai kebiasaan sarapan siswa disekolah dasar didapatkan bahwa 46,3\% anak selalu sarapan, 41,3\% kadang-kadang sarapan dan sisanya $12,4 \%$ tidak pernah sarapan. ${ }^{7}$ Penelitian oleh Gajre di India yang melibatkan anak usia 11-13 tahun menyebutkan sebanyak $62,3 \%$ terbiasa sarapan setiap hari dan 33,8\% hanya 2-3 kali dalam seminggu melakukan sarapan. Selain itu, pada survey oleh Pergizi Pangan Indonesia menyebutkan 44,6\% anak usia sekolah dasar yang sarapan hanya memperoleh asupan energi sebanyak $15 \%$ dari kebutuhannya.

Sarapan sering dianggap remeh oleh sebagian orang, namun efek negatifnya cukup buruk. Makan pagi sangat penting dan bermanfaat bagi semua orang. ${ }^{7}$ Semua zat gizi yang berasal dari makan malam telah dikonversi menjadi energi dan diedarkan ke seluruh tubuh. Sementara jarak waktu makan malam dan bangun pagi sekitar 8 jam. Ketika tidur, proses oksidasi dan metabolisme dalam tubuh tetap berlangsung dan hal ini menyebabkan kadar glukosa dalam darah berkurang ketika pagi hari. Untuk mengganti glukosa darah yang berkurang maka dibutuhkan cadangan sumber hidrat arang. Namun bila cadangan tersebut habis, maka tubuh akan mengambil cadangan dari lemak. Kehilangan glukosa darah saat pagi hari mempengaruhi aktivitas pekerjaan pagi hari. ${ }^{8}$ Menurut Saidin, anak yang tidak terbiasa sarapan akan mempunyai kadar glukosa yang rendah. Glukosa darah adalah satu-satunya penyalur energi bagi otak untuk bekerja optimal. Glukosa yang rendah hingga mencapai $<70 \mathrm{mg} / \mathrm{dl}$ akan menyebabkan penurunan konsentrasi belajar atau daya ingat, tubuh melemah, pusing dan gemetar. ${ }^{9}$

Menurut Soekirman anak yang tidak terbiasa sarapan mengalami kesulitan mengerjakan tugas di kelas yang memerlukan konsentrasi, sering mempunyai nilai hasil ujian yang rendah, mempunyai daya ingat yang terbatas dan sering absent. Selain itu dari berbagai penelitian membuktikan bahwa sarapan berpengaruh pada konsentrasi dan prestasi belajar anak sekolah. ${ }^{10}$ Hasil penelitian Kurniasari menunjukan pada anak sekolah dasar di Yogyakarta menunjukan terdapat hubungan yang nyata antara asupan energi makan pagi dengan konsentrasi di sekolah. ${ }^{11}$ Hasil penelitian Sobaler pada 130 anak sekolah usia 6 13 tahun di Madrid menunjukan bahwa terdapat hubungan antara presentase asupan energi sarapan terhadap total energi dengan kemampuan intelektual anak. ${ }^{12}$

Dehidrasi merupakan kondisi ketidakseimbangan cairan tubuh dikarenakan pengeluaran cairan lebih besar daripada pemasukan. Dehidrasi disebabkan karena cuaca panas, konsumsi obat diuretik serta kurangnya konsumsi cairan. ${ }^{13}$ Menurut Gustam, dehidrasi lebih banyak terjadi pada remaja $(48,1 \%)$ dibandingkan dewasa $(44,5 \%) .{ }^{14}$ Pada penelitian Tawaniate menyebutkan bahwa dehidrasi pada kelompok remaja akhir mencapai 70,1\%. 15 Kurangnya konsumsi cairan merupakan salah satu penyebab rentannya remaja mengalami dehidrasi. Hal ini disebabkan semakin banyak aktivitas yang membutuhkan banyak tenaga dan cairan. Konsumsi cairan remaja sebagian besar (79\%) diperoleh dari minuman dan sisanya (21\%) dari makanan. ${ }^{16}$ Remaja lebih memilih air putih sebagai penyumbang cairan terbesar. Penelitian yang dilakukan di Bogor menyebutkan terdapat 37,3\% remaja minum kurang dari 8 gelas per hari dan $24,1 \%$ mengasup cairan kurang dari $90 \%$ dari kebutuhan. Rata-rata remaja mengkonsumsi cairan $2585 \mathrm{ml}$ per hari. ${ }^{17}$ Penelitian di Tangerang pada 92 subjek menyebutkan sebanyak 57,6 siswa dan siswi mengalami dehidrasi dan $38 \%$ tidak mengetahui kebutuhan cairan bagi tubuh setiap hari. ${ }^{18}$ Penelitian di Singapura menyebutkan bahwa 
remaja dan orang dewasa muda lebih berisiko mengalami dehidrasi dibanding kelompok lainya. ${ }^{19}$

Dehidrasi terkait dengan aspek fungsi kognitif salah satunya adalah konsentrasi. Dehidrasi timbul tanpa gejala dan selanjutnya akan berakibat pada gangguan kognitif, koma bahkan kematian. Status hidrasi yang buruk berakibat pada gangguan fungsi kognitif, fungsi neurologik dan pada akhirnya akan mempengaruhi kualitas hidup. ${ }^{20,21}$

Berdasarkan uraian di atas penelitian ini bertujuan untuk mengetahui dan menganalisis hubungan kebiasaan sarapan pagi dan status hidrasi dengan konsentrasi berfikir pada remaja.

\section{METODE}

Penelitian ini menggunakan rancangan cross sectional yang dilakukan pada bulan Juni 2014. Populasi target dalam penelitian ini adalah seluruh siswi SMA/SMK di Surakarta, dan populasi terjangkaunya adalah siswi dari SMK Batik 2 Surakarta. Subjek dalam penelitian ini adalah siswi yang bersekolah di SMK Batik 2 . Cara pengambilan sampel menggunakan metode simple random sampling. Besar sampel penelitian dihitung dengan menggunakan rumus estimasi proporsi dengan koreksi drop out $10 \%$. Berdasarkan perhitungan besar sampel tersebut maka jumlah minimal sebanyak 80 orang. Kriteria inklusi sampel adalah usia 15 - 19 tahun, remaja perempuan, tidak sedang menderita penyakit infeksi dan non infeksi, tidak dalam sedang menstruasi, tidak mengkonsumsi obat diuretik, serta bersedia mengisi lembar informed consent.

Penelitian ini diawali dengan mengumpulkan data karakteristik subjek yaitu identitas diri, usia, berat badan, tinggi badan, kebiasaan sarapan, status hidrasi dan konsentrasi berfikir. Berat badan diukur dengan menggunakan timbangan digital dengan kapasitas 0,1 kilogram. Tinggi badan diukur menggunakan microtoise dengan ketelitian 0,1 centimeter. Pengambilan data kebiasaan sarapan dilakukan dengan menggunakan kuasioner kebiasaan sarapan. Data status hidrasi diperoleh dengan pemeriksaan berat jenis urin dengan metode pycnometer yang dilakukan di laboratorium. Sedangkan data konsentrasi berfikir diperoleh dengan menggunakan metode digit symbol test dan digit span test dari subtest WAIS yang dilakukan oleh lembaga psikologi terapan yang tersertifikasi.

Variabel bebas dalam penelitian ini adalah kebiasaan sarapan dan status hidrasi. Variabel terikat dalam penelitian ini adalah konsentrasi berfikir. Analisis data menggunakan program komputer .

Analisis univariat dilakukan terhadap data usia responden, indeks massa tubuh ( IMT), kebiasaan sarapan, status hidrasi, dan konsentrasi berfikir. Indeks massa tubuh ( IMT ) diinterpretasikan dengan menggunakan nilai $z-$ score. Nilai $z$ - score dikategorikan menjadi 4, yaitu > +2SD tergolong kategori kegemukan obesity ), > 1 SD kategori kelebihan berat badan 1 SD sampai dengan +1 SD tergolong kategori normal, <-2SD tergolong kategori kurus (thinnes ). ${ }^{22}$ Kebiasaan sarapan dikategorikan menjadi 2 yaitu biasa sarapan yaitu responden setiap hari melakukan kegiatan sarapan dan tidak terbiasa sarapan yaitu tidak pernah melakukan sarapan atau jarang melakukan sarapan. Analisis status hidrasi menggunakan nilai berat jenis urin. Nilai berat jenis $1,010-1,025 \mathrm{~g} /$ mldikategorikan normal (baik), sedangkan nilai berat jenis 1,025 - 1,030 dikategorikan dehidrasi. Kemampuan konsentrasi berfikir dikategorikan menjadi 2 yaitu kategori rendah apabila skor konsentrasi $<18$ dan kategori tinggi apabila skor konsentrasi $>19$.

Analisis hubungan antara variabel bebas dan variabel terikat terlebih dahulu dilakukan dengan uji kenormalan Kolmogorov Smirnov. Variabel yang diteliti yaitu kebiasaan sarapan, status hidrasi dan konsentrasi berfikir. Analisis bivariat dilakukan dengan menggunakan uji Chisquare. Analisis bivariat dilakukan untuk mengetahui adanya hubungan antara variabel terikat, yaitu konsentrasi berfikir dengan variabel bebas, yaitu kebiasaan sarapan dan status hidrasi.

\section{HASIL \\ Karakteristik subjek}

Rentang usia subjek dalam penelitian ini 15 - 19 tahun dengan frekuensi terbesar yaitu usia 17 tahun sebanyak 44 subjek ( $55 \%$ ). Kategori status gizi diperoleh berdasarkan nilai $z$-score BMI menurut usia 5 - 19 tahun. Hasil pengukuran antropometri berupa indeks massa tubuh yang diinterprestasikan dengan $z$-score menunjukkan bahwa sebanyak 19 subyek ( $30 \%$ ) tergolong dalam kategori status gizi kurus dan 2 subyek ( 2,5 $\%)$ tergolong kategori obesitas.

Dari tabel 1 diketahui bahwa subyek yang terbiasa melakukan sarapan 42 subyek ( $52,5 \%$ ) lebih banyak daripada subyek yang tidak terbiasa melakukan sarapan 38 subyek ( $27,5 \%$ ). Sebanyak 56 subyek ( $70 \%$ ) memiliki nilai berat jenis urin di atas normal atau subyek mengalami dehidrasi. Deskripsi frekuensi subyek menurut status hidrasi disajikan pada tabel 1. 
Skor konsentrasi berfikir pada 80 subyek hampir seimbang, terdapat 37 subyek ( 46,25\%) memiliki skor konsentrasi berfikir rendah dan 43 subyek ( $51,75 \%)$ memiliki skor konsentrasi berfikir tinggi yang disajikan pada ( tabel 1).

Tabel 1. Karakteristik Subjek Penelitian

\begin{tabular}{lcc}
\hline \multicolumn{1}{c}{ Variabel } & N & Persen ( \%) \\
\hline Usia & 4 & 5 \\
15 & 23 & 28,75 \\
16 & 44 & 55 \\
17 & 8 & 10 \\
18 & 1 & 1,25 \\
19 & & \\
Status Gizi & 19 & 30 \\
Kurus & 57 & 71,25 \\
Normal & 2 & 2,5 \\
Kelebihan berat badan & 2 & 2,5 \\
Obesitas & & \\
Kebiasaan Sarapan & 38 & 47,5 \\
Tidak biasa sarapan & 42 & 52,5 \\
Biasa sarapan & & \\
Status hidrasi & 56 & 70 \\
Dehidrasi & 24 & 30 \\
Normal & & \\
Konsentrasi berfikir & 37 & 48,25 \\
Rendah & 43 & 51,75 \\
Tinggi & & \\
\hline
\end{tabular}

\section{Kebiasaan Sarapan}

Dari hasil analisis uji Chi-square

sarapan dan mempunyai skor konsentrasi berfikir didapatkan terdapat hubungan antara kebiasaan sarapan dan kemampuan konsentrasi berfikir. Proporsi remaja yang mempunyai kebiasaan yang tinggi lebih banyak yaitu 36 subyek dibandingkan remaja yang tidak biasa sarapan dan mempunyai skor konsentrasi berfikir rendah sebanyak 31 subyek (tabel 2).

Tabel 2. Hubungan kebiasaan sarapandengan konsentrasi berfikir

\begin{tabular}{lccc}
\hline \multirow{2}{*}{ Kebiasaan sarapan } & \multicolumn{2}{c}{ Konsentrasi berfikir } & \multirow{2}{*}{$\mathrm{P}$} \\
\cline { 2 - 3 } & Rendah & Tinggi & 0,00 \\
\hline Tidak biasa sarapan & 31 & 7 & \\
Biasa sarapan & 6 & 36 & \\
Total & 37 & 43 & \\
\hline
\end{tabular}

\section{Status Hidrasi}

Dari hasil analisis uji Chi-square didapatkan tidak terdapat hubungan antara status hidrasi dan konsentrasi berfikir. Proporsi remaja yang dehidrasi dan mempunyai skor konsentrasi berfikir yang rendah lebih banyak yaitu 24 subyek daripada yang dehidrasi dan mempunyai skor konsentrasi berfikirtinggi (tabel 3)

Tabel 3.Hubungan status hidrasidengan konsentrasi berfikir

\begin{tabular}{lccc}
\hline \multirow{2}{*}{ Status Hidrasi } & \multicolumn{2}{c}{ Konsentrasi berfikir } & \multirow{2}{*}{ P } \\
\cline { 2 - 3 } & Rendah & Tinggi & \\
\hline Dehidrasi & 24 & 13 & 0,36 \\
Normal & 32 & 11 & \\
Total & 56 & 24 & \\
\hline
\end{tabular}

\section{PEMBAHASAN}

\section{Kebiasaan Sarapan}

Sarapan pagi merupakan kegiatan yang bertujuan untuk mencukupi kebutuhan energi selama beraktivitas terutama pada anak sekolah.
Selain itu, sarapan juga berperan dalam meningkatkan konsentrasi dan daya ingat anak sehingga diharapkan dapat meningkatkan prestasi. ${ }^{6}$ Penelitian ini menggunakan 80 subjek siswi dari SMK 2 Batik Surakarta. 
Pada penelitian ini subjek yang terbiasa sarapan sebesar $52,5 \%$ dan tidak terbiasa sarapan 47,5 \%. Pada penelitian oleh Rampersaud di Amerika Serikat menyebutkan bahwa $30 \%$ remaja di usia 15 - 18 tahun tidak terbiasa sarapan. Menurut Ramperseud sarapan sangat penting dan bermanfaat bagi semua orang. Semua zat gizi yang diperoleh dari makan malam sudah diubah dan diedarkan ke seluruh jaringan tubuh. Sementara jarak waktu makan malam dan bangun pagi sekitar 8 jam. Selama tidur, metabolisme dalam tubuh tetap berlangsung, akibatnya pada pagi hari perut sudah kosong. ${ }^{4}$

\section{Status Hidrasi}

Dari hasil uji berat jenis urin didapatkan sebanyak $70 \%$ mengalami dehidrasi dan $30 \%$ subjek tidak mengalami dehidrasi ( normal ). Hal tersebut lebih tinggi daripada penelitian sebelumnya yang dilakukan bahwa $65,3 \%$ subjek mengalami dehidrasi. Faktor faktor yang mempengaruhi status hidrasi pada subjek antara lain adalah aktivitas yang dilakukan sebelum sampel urine diambil, asupan cairan yang diasup oleh subjek tidak memenuhi kebutuhan asupan cairan yang seharusnya. Asupan cairan yang dianjurkan sekitar 1, 5-2 L untuk remaja putri. ${ }^{23}$

Masa remaja cenderung memiki aktivitas yang tinggi. Tingginya aktivitas menyebabkan meningkatnya kebutuhan konsumsi cairan. Penelitian oleh Briawan menyebutkan 37,3\% remaja minum kurang dari 8 gelas per hari dan $24,1 \%$ mengasup cairan kurang dari $90 \%$ dari kebutuhan sehari-hari. ${ }^{17}$

\section{Konsentrasi Berfikir}

Dari hasil test konsentrasi berfikir menggunakan metode digit symbol test dan digit span test yang dilakukan didapatkan sebanyak 37 subyek ( $48,25 \%)$ mempunyai skor konsentrasi berfikir rendah dan sebanyak 43 ( 51,75 \%) subyek mempunyai skor konsentrasi berfikir tinggi Hal tersebut lebih tinggi dari penelitian yang dilakukan di Pontianak dengan menggunakan metode yang sama yaitu $45 \%$ subyek mempunyai kosentrasi berfikir tinggi .

Beberapa faktor yang mempengaruhi konsentrasi berfikir adalah faktor usia, dimana usia ikut berpengaruh dalam kemampuan konsentrasi individu. Selain usia faktor fisik yang pada saat test konsentrasi tersebut dilakukan juga sangat berpengaruh, misalnya kondisi kelelahan dan keadaan sakit yang dialami subyek akan mempengaruhi kemampuan sistem saraf. Dan selain faktor usia dan kondisi fisik, faktor pengalaman dan pengetahuan juga berpengaruh terhadap konsentrasi, karena individu akan memusatkan perhatian pada objek yang belum bisa dikenali polanya sehingga pengalaman pengetahuan individu dapat memudahkan kosentrasi. $^{7}$

\section{Hubungan Antara Kebiasaan Sarapan dengan Konsentrasi Berfikir}

Hasil penelitian menunjukkan bahwa kelompok remaja yang terbiasa sarapan memiliki nilai rata - rata skor konsentrasi berfikir lebih tinggi dibandingkan dengan kelompok remaja yang tidak terbiasa melakukan sarapan. Hasil analisa statistik menggunakan Chi-square menunjukkan terdapat hubungan yang bermakna antara konsentrasi berfikir dengan metode digit symbol test dan digit span test antara kelompok remaja yang terbiasa sarapan dengan kelompok remaja yang tidak terbiasa sarapan $(\mathrm{p}=0,00)$.

Anak yang tidak terbiasa sarapan akan berdampak pada kemampuan konsentrasi ketika mengerjakan tugas di kelas. Hal ini serupa dengan pendapat Rifameutika bahwa perilaku belajar anak salah satunya merupakan dampak positif dari sarapan. Anak yang terbiasa sarapan akan menjadi lebih bersemangat belajar, konsentrasi dan daya ingat meningkat serta kondisi emosional anak cenderung baik. Menurut Leane, sarapan berperan dalam menjaga fungsi kognisi. Konsentrasi berfikir merupakan bagian dari fungsi kognisi. Kondisi kosongnya lambung dapat membuat kadar glukosa darah menurun. Kondisi glukosa yang menurun akan mengakibatkan pasokan glukosa bagi otak terganggu. ${ }^{24}$

Glukosa darah merupakan salah satu faktor untuk menjaga fungsi saraf. Kadar glukosa darah bervariasi tergantung pada asupan zat gizi. Kebiasaan sarapan akan memelihara glukosa darah dalam batas normal. Pada penelitian ini, terdapat hubungan kebiasaan sarapan terhadap kemampuan konsentrasi berfikir. Sarapan pagi merupakan sumber glukosa yang baik. Glukosa merupakan sumber energi utama untuk kerja otak. Apabila kadar glukosa turun, glukosa-6-fosfat di hati akan diubah menjadi glukosa sehingga kadar glukosa darah meningkat. Jaringan lain tidak mempunyai enzim glukosa-6-fosfatase sehingga tidak dapat mengubah glukosa-6-fosfat menjadi glukosa. Glukosa-6-fosfat akan mengalami katabolisme melalui Embden-Meyerhoff Pathway dan Heksosamonofosfat-shun. Apabila persediaan glukosa darah turun, hati akan mengubah sebagian dari glikogen menjadi glukosa dan mengeluarkannya ke dalam aliran darah. Glukosa ini akan dibawa oleh darah ke seluruh bagian tubuh yang memerlukan salah satunya otak. ${ }^{7}$ Menurut Soekirman anak yang tidak terbiasa makan pagi 
akan berdampak pada konsentrasi ketika mengerjakan tugas di kelas. Hal ini akan berakibat pada menurunnya prestasi di sekolah. ${ }^{10}$

Hasil penelitian ini sesuai dengan beberapa penelitian sebelumnya tentang hubungan kebiasaan sarapan pagi dengan konsentrasi. Hasil penelitian Mochtar pada remaja sekolah menengah atas di kota Pontianak menunjukkan bahwa terdapat hubungan konsentrasi berfikir menggunakan metode digit symbol test dan digit span test antara remaja yang sarapan dengan remaja yang tidak sarapan. $^{7}$ Hasil penelitian Kurniasari pada anak sekolah dasar di Yogyakarta menunjukkan terdapat hubungan antara asupan energi yang berasal dari makan pagi dengan konsentrasi di sekolah menggunakan digit symbol test. ${ }^{11}$

\section{Hubungan Antara Status Hidrasi dengan Konsentrasi Berfikir}

Hidrasi dapat diartikan keseimbangan cairan dalam tubuh serta kaitannya dengan fungsi metabolisme di dalam tubuh. Terjadinya ketidakseimbangan cairan yang keluar dan masuk dalam tubuh berakibat dehidrasi. Selain itu, dehidrasi dapat muncul tanpa gejala. ${ }^{20}$ Ada tiga jenis dehidrasi yaitu hypotonic, hypertonic dan isotonic. Akibat dari kondisi dehidrasi dapat mempengaruhi fungsi kognitif yaitu menurunnya kemampuan konsentrasi, kewaspadaan dan memori jangka pendek. Konsumsi cairan yang tidak adekuat akan menyebabkan remaja rentan mengalami dehidrasi.

Hasil penelitian ini menunjukkan proporsi remaja yang dehidrasi lebih banyak yang mempunyai skor konsentrasi berfikir tinggi daripada yang normal. Selain itu tidak terdapat hubungan antara status hidrasi dengan konsentrasi berfikir. Hal ini tidak sesuai dengan pendapat Whitmire yang menyebutkan bahwa gejala dehidrasi akut bervariasi sesuai dengan pengurangan berat badan. Pada kehilangan berat badan 5-6\% akan menimbulkan sulit berkonsentrasi, sakit kepala, kegagalan pengaturan suhu dan peningkatan frekuensi nafas. Dalam beberapa kasus, pada kondisi dehidrasi 2-2,6\% tidak berpengaruh terhadap fungsi kognitif. Pada penelitian yang dilakukan oleh D'Anci menyebutkan bahwa efek yang ditimbulkan oleh keadaan dehidrasi ringan hanya pada suasana hati (mood), tidak disebutkan pada konsentrasi. ${ }^{13}$ Selain itu pada penelitian yang dilakukan oleh Szinnai menyebutkan bahwa keadaan dehidrasi 2,6\% tidak menyebabkan perubahan pada fungsi kognitif. ${ }^{15}$

\section{SIMPULAN}

1. Kebiasaan sarapan terbukti bermakna meningkatkan konsentrasi berfikir $(\mathrm{p}=0,00)$.

2. Status hidrasi tidak terbukti meningkatkan konsentrasi berfikir ( $\mathrm{p}=0,36)$.

\section{SARAN}

1. Perlunya diadakan edukasi bagi siswi tentang pentingnya melakukan kebiasaan sarapan yang dapat berperan sebagai salah satu upaya peningkatan konsentrasi berfikir di sekolah.

2. Perlunya diadakan edukasi bagi siswi tentang pentingnya memperhatikan status hidrasi melalui konsumsi cairan yang sesuai kebutuhan guna menjaga konsentrasi berfikir di sekolah.

\section{DAFTAR PUSTAKA}

1. Jellife, D.B and Jellife, E.F.P.1989. Community Nutrional Assessment. Oxford University Press : New York

2. Soekirman. 1993. Masalah Gizi dalam pembangunan Jangka Panjang Kedua : Agenda Repelita VI. Makalah pada Widyakarya Nasional Pangan dan Gizi. Jakarta: LIPI

3. Gajre NS, Fernandez S, Balakrishna N, Vazir S. 2008. Breakfast eating habit and its inlfluensce on attention-concentration, immediate memory and school achievement. Indian Pediatr ;45(10):824-4..

4. Rampuaserd, G. C. Pereira, M. A, Girard, B.L., Adams, J And J. D. 2005 . Review : Breakfast Habits, Nutritional Status, Body Weight, and Academic Performance in Children and Adolencenst. Journal of America Dietetic Association ; 105: 743- 760

5. Rahcmawati, I. 2007. Hubungan Antara Tingkat Pengetahuan Gizi, Sarapan Pagi Dengan Prestasi Belajar Siswa di SMP Negeri 5 Kebumen. Sripsi Universitas Gadjah Mada.

6. Triyanti. 2005. Hubungan Kebiasaan Makan Pagi dengan Prestasi Belajar pada Anak SD Kelas V Sekolah Dasar Negeri Citarum 01-02-03-04 Semarang Tahun 2005 ( Skripsi ). Semarang : Universitas Negeri Semarang.

7. Muctar, Muhammad., Julia Madarina., Gamayanti Indira Laksmi. ( 2011) Sarapan dan Jajan Berhubungan Dengan Kemampuan Konsentrasi Pada Remaja. Jurnal Gizi Klinik Indonesia,8 (1) 28 -35 .

8. Faridi, A. 2002. Hubungan sarapan pagi dan kadar glukosa darah dengan konsetrasi belajar pada siswa sekolah dasar. Jurusan Gizi Mayarakat dan sumberdaya Keluarga. Fakultas Pertanian. Institut Pertanian Bogor

9. Saidin, S. 2002 . Hubungan Kebiasaan Makan Pagi dengan Konsentrasi Belajar. Bogor : Pusat Penelitian Gizi dan Pengembangan Gizi Badan Litbangkes Depkes RI Jakarta. 
10. Soekirman . 2000 . Imu Gizi dan Aplikasinya . Dirgen Dikti Depdiknas RI, Jakarta.

11. Kurniasari, Rita . 2005 . Hubungan Frekuensi dan Asupan Gizi Makan Pagi Dengan KADAR Hemoglobin ( $\mathrm{Hb}$ ) Darah dan Konsentrasi di Sekolah Pada Murid Kelas V dan VI SDN Jetis 1 dan SDN jetishardjo 1. Yogyakarta: Gadjah Mada University Press

12. Sobaler, A.M.L,. Ortega, R.M., Quintas, M.E, B. \& Requejo, A. M. 2003. Relationship between Habitual Breakfast and Intellectual Performance Logical Reasoning in Well- Nourshed Scholchildreb of Madrid ( Spain ). European Journal of Clinical Nutritional, suppl 1, S49 - s53.

13. D'Anci KE, Constant F, Rosenberg IH. 2008. Hydration and cognitive function in children. Nutrition Reviews. DOI: 10.1111/j.1753-4887.

14. Gustam, Hardinsyah, Dodik Briawan. 2012. Faktor Risiko Dehidrasi pada Remaja dan Dewasa. Skripsi Institut Pertanian Bogor.

15. Schwabe L, Szinnai G, Keller U, Schachninger H. Dehydration does not influence cardiovascular reactivity to behavioural stress in young healthy humans. Clin Physiol Imaging. 27(5):291-7

16. Sigit Oktaviayani Prayitno, Fillah Fithra Dieny.2012. Perbedaan Konsumsi Cairan dan Status Hidrasi Pada Remaja Obesitas dan Non Obesitas. Journal of Nutrition College.

17. Hardinsyah, Endang S. Soenaryo, Dodik Briawan, Evy Damayanthi, Cesila M. Dwiriani.2008. Studi Kebiasaan Minum dan Hidrasi pada Remaja dan Dewasa di Dua Wilayah Ekologi yang Berbeda. Bogor : Perhimpunan Peminat Gizi dan Pangan Indonesia (PERGIZI), Departemen Gizi Masyarakat FEMA IPB; 2009.

18. Naya Riance. 2011. Gambaran Status Hidrasi Pada Siswa dan Siswi SMA Triguna Utara Ciputat (Skripsi). Fakultas Kesehatan Masyarakat Universitas Indonesia.

19. Barry M. Popkin, D’anci KE, Rosenberg IH. 2010. Water, hydration and health. Nutr Rev. 68(8): 439458. doi:10.1111/j.1753-4887.2010.00304.

20. Cian C, Koulmann N, A P, Raphel C, Jimenez C, Melin B. Influences of variations in body hydration on cognitive function: Effect of hyperhydration, heat stress, and exercise--induced dehydration. Journal of Psychophysiology. 2000;14(1):29-36.

21. Wilson M-MG, Morley JE. 2003. Impaired cognitive function and mental performance in mild dehydration. European Journal of Clinical Nutrition ,57, Suppl 2, S24-S29.

22. Gibson, R.S (2005) Priciples of Nutrition, Assesment, Second Edition, Oxford Universty Press, New York.

23. Gabor Szinnai, Schachninger, Maurice J Arnaud, Lily Linder, Ulrich Keller. 2005. Effect of water deprivation on cognitive-motor performance in healthy men and women. Am J Physiol Integr Comp Physiol. R275-R280.
24. Breaksfast Science Library . 2008. Ovierviews on Breakfast Science Topic. Factors influencing breakfast skipping behavior in adult and adolencents. 